\title{
Mulher(es) em meio à pandemia: o que as capas das revistas femininas têm a dizer/ensinar?
}

\author{
Felipe Viero KOLINSKI MACHADO ${ }^{1}$ \\ Vanessa Costa TRINDADE ${ }^{2}$
}

\begin{abstract}
Resumo:
Em meio à pandemia de Covid-19, quais sentidos se constituem nas capas das revistas femininas? Recuperamos as noções de acontecimento, mega-acontecimento e não-acontecimento jornalístico, bem como estudos sobre gênero, revistas femininas/jornalismo masculino e a importância do estudo das capas. A partir das capas das edições de maio de 2020 de Claudia, Vogue, Marie Claire e Glamour, compreendidas como dispositivos midiáticos que inscrevem textos verbo-visuais e, ainda, como dispositivos discursivos das feminilidades, observamos lugares plurais de representação, os quais sinalizam um discurso essencialista no que tange à compreensão do que é ser mulher, a preponderância de um não-acontecimento frente a um mega-acontecimento, lógicas patriarcais e heteronormativas naquilo que se refere às possibilidades de ser mulher e, ainda, um futuro, pós-pandemia, com possibilidades de ser marcado pela solidariedade e pelo apoio feminino.
\end{abstract}

Palavras-chave: capas de revistas femininas; pandemia de Covid-19; verbovisualidades; dispositivo discursivo das feminilidades.

\section{Woma(e)n on the pandemic: what do the covers of women's magazines have to say/teach?}

\begin{abstract}
:
During the Covid-19 pandemic, what meanings are included in the covers of women's magazines? We recovered the notions of event, mega-event and journalistic non-event, as well as studies on gender, women's magazines / male journalism and the importance of the study of covers. From the covers of the May 2020 editions of Claudia, Vogue, Marie Claire and Glamour, understood as media dispositive that inscribe verb-visual texts and, still, as discursive dispositive of femininities, we observe plural places of representation, which signal a essentialist discourse regarding the understanding of what it means to be a woman, the preponderance of a non-event in front of a mega-event, patriarchal and heteronormative logic in what refers to the possibilities of being a woman and, still, a future, post-pandemic, with possibilities of being marked by solidarity and female support.
\end{abstract}

Keywords: women's magazine covers; Covid-19 pandemic; verbovisualities; discursive device of femininities

\footnotetext{
${ }^{1}$ Doutor em Ciências da Comunicação pela Universidade do Vale do Rio dos Sinos (UNISINOS). Docente dos cursos de Jornalismo e do Programa de Pós-Graduação em Comunicação da Universidade Federal de Ouro Preto (UFOP).E-mail: felipeviero@gmail.com.

${ }^{2}$ Doutora pelo Programa de Pós-Graduação em Comunicação Social da Universidade Federal de Minas Gerais (UFMG), professora do Instituto de Educação Continuada da Pontifícia Universidade Católica de Minas (PUC Minas).E-mail: vancotrin@gmail.com.
} 


\title{
Mujer(es) en medio de la pandemia: ¿qué tienen que decir/enseñar las portadas de las revistas femeninas?
}

\begin{abstract}
Resumen:
En medio de la pandemia de Covid-19, ¿qué significan las portadas de las revistas femeninas? Recuperamos las nociones de evento, megaevento y no evento periodístico, así como estudios sobre género, revistas femeninas / periodismo masculino y la importancia del estudio de portadas. Desde las portadas de las ediciones de mayo de 2020 de Claudia, Vogue, Marie Claire y Glamour, entendidas como dispositivos mediáticos que inscriben textos verbo-visuales y, aún, como dispositivos discursivos de las feminidades, observamos lugares de representación plurales, que señalan una discurso esencialista sobre la comprensión de lo que es ser mujer, la preponderancia de un no-evento ante un mega-evento, lógicas patriarcales y heteronormativas sobre las posibilidades de ser mujer e, incluso, un futuro pos pandémico, con posibilidades de estar marcado por la solidaridad y el apoyo femenino.
\end{abstract}

Palabras clave: portadas de revistas femeninas; pandemia de Covid-19; verbovisualidades; dispositivo discursivo de las feminidades.

\section{Introdução}

Percebemos o acontecimento como um fenômeno de ordem hermenêutica que, por um lado, pede para ser compreendido e que, por outro, possui um poder de revelação. Inscrevendose em determinado tempo/espaço, seria aquele fato que possuiria o potencial de gerar rupturas e que sinalizaria níveis de significação (campos problemáticos) que, então, poderiam estar submersos. Acontecimentos, entretanto, são plurais, bem como os modos de percebê-los e de não percebê-los (QUÉRÉ, 2005; REBELO, 2006).

Santos (2005) emprega a expressão "mega-acontecimento" ao fazer referência àqueles que possuem uma importância potencializada, ultrapassando os sentidos disponíveis para sua explicação. A Covid-19, doença respiratória grave causada pelo novo coronavírus, foi identificada pela primeira vez em dezembro de 2019. Em março de 2020, a Organização Mundial da Saúde declarou a pandemia: os números globais giravam em torno de 120 mil contaminações e de cerca de 4 mil óbitos (MOREIRA; PINHEIRO, 2020, não paginado). Enquanto escrevemos, ${ }^{3}$ há mais de 32 milhões de casos ao redor do mundo e óbitos beiram a funesta marca de 1 milhão (COVID-19 DASHBOARD..., 2020). No Brasil, são mais de 4 milhões e 600 mil casos e mais de 140 mil mortes (BRASIL..., 2020, não paginado).

O vírus em si, disse Butler (2020), não discrimina, mas as desigualdades sociais e econômicas, sim. Preciado (2020), em diálogo, lembra que as epidemias materializam no

\footnotetext{
${ }^{3}$ Texto escrito em setembro de 2020.
} 
âmbito do corpo individual as obsessões que dominam a gestão política da vida e da morte das populações. Zizek (2020) sugere que a pandemia de coronavírus representaria uma espécie de ataque ao sistema capitalista global, uma vez que explicitaria a necessidade de uma mudança radical.

Essas ponderações revelam apenas alguns dos diversos campos problemáticos evidenciados pela pandemia. Parece-nos óbvio - tendo em vista a irrupção da vida cotidiana, as rupturas então geradas e a importância potencializada - que se trata de um novo megaacontecimento.

Contudo, ao refletirmos sobre a cobertura midiática em torno da pandemia, ainda que soe paradoxal, igualmente faz-se necessário retomar a discussão sobre não-acontecimento jornalístico. Para Fontcuberta (1993), o não-acontecimento jornalístico faria referência à construção, à produção e à difusão de notícias a partir de fatos não ocorridos ou que correspondam a uma não informação. O não-acontecimento jornalístico romperia com a ideia de atualidade e desvirtuaria a essência do jornalismo (informando sobre o que não acontece).

Quando nos deparamos com as capas de revistas femininas que analisaremos aqui ( $1^{\mathrm{a}}$ semana - maio/2020), o que mais nos perturbou foi a percepção de que embora a mídia, de modo geral, abordasse fundamental e exaustivamente a pandemia de Covid-19, a repercussão não era a mesma entre os veículos destinados às mulheres. Se mediante breve recuperação histórica (MIRA, 1997; BUITONI, 2013) já é possível constatar a predominância de uma mídia que visava mais a entreter mulheres em espaços físicos e simbólicos pré-estabelecidos como de interesse feminino do que, de fato, informá-las e incluí-las em debates públicos e sociais mais amplos, seria possível que, em plena pandemia, com números de contaminação e de óbitos em franco crescimento, ${ }^{4}$ o mesmo seguisse ocorrendo?

Perceber de que modo, nas capas das revistas Claudia, Vogue, Marie Claire e Glamour, a pandemia de Covid-19 era/não era representada, naquele período específico, consiste na nossa questão norteadora. Para além das reflexões evocadas nesta introdução, acionaremos referências teóricas, metodológicas e epistemológicas para pensarmos sobre

\footnotetext{
${ }^{4}$ Em 08 de maio, dia em que nos deparamos com a maior parte destas capas, o país registrava cerca de 150 mil casos de contaminação e cerca de 10 mil óbitos. Em nível mundial, registravam-se mais de 3,8 milhões de contaminações e cerca de 270 mil óbitos (CASOS..., 2020; COVID-19: OS NÚMEROS..., 2020).
} 
gênero, revistas femininas/jornalismo masculino e a importância do estudo das capas e, então, apresentaremos uma breve análise.

Os lugares a partir dos quais compreendemos o gênero e, então, as revistas femininas

Tal qual lembra Preciado (2014, p. 29), ainda que se apresente como a "expressão instintiva da verdade pré-discursiva da carne", a identidade sexual consistiria em uma construção. Indo ao encontro das ponderações de Wittig (2010), podemos compreender, ainda, que na divisão masculino/feminino tem-se uma categorização que dissimularia o fato de que as diferenças sociais implicariam uma ordem econômica, política e ideológica. Butler (2012), nesse mesmo sentido, postula que o gênero, performativo, corresponde a uma repetição que se dá no corpo, não sendo, portanto, a-histórico e invariável. Perceber o caráter ficcional do gênero, entretanto, não significa dizer que ele não seja efetivo, que não construa hierarquias e que não consolide uma sociedade patriarcal (SAFFIOTI, 2015) e heteronormativa (WARNER, 1991).

Nesse mesmo sentido, torna-se importante recuperar as reflexões de Lauretis (1994). Para a pesquisadora, várias tecnologias poderiam produzir, promover e implantar representações de gênero. Ainda que suas reflexões sejam voltadas ao cinema, pensamos que tais elucubrações podem ser mobilizadas para que pensemos sobre as revistas. Ao passo que se voltam às mulheres, essas revistas dizem, também, o que é e o que não é de interesse feminino, inserem-se em uma cadeia discursiva mais ampla que, do mesmo modo, ensina sobre o que é ser/sobre o que não é ser mulher, portando-se como dispositivos discursivos que dizem de feminilidades possíveis ${ }^{5}$ (KOLINSKI MACHADO, 2018).

\section{O que significa ser um veículo feminino em um jornalismo cujo gênero é o masculino?}

Conforme lembram Tavares e Schwaab (2013), Mercúrio Galante foi uma publicação de interesse geral, que trazia crônicas, anedotas e poesias, surgida em 1672. Um "correlato" feminino (Mercúrio para Senhoras) teria sido desenvolvido em 1693, trazendo modelos de

\footnotetext{
${ }^{5}$ Em pesquisa anterior, ancorados em Fischer (2002), propusemos o conceito de dispositivo discursivo das masculinidades, fazendo então alusão aos "aparatos que, inseridos em determinada ordem discursiva, dão a ver quais são as possibilidades (e as impossibilidades) de se ser e de se estar no mundo como gay e como homem heterossexual" (KOLINSKI MACHADO, 2018). Em investigações mais recentes temos recuperado/repensado tal noção em relação também às mulheres.
} 
roupas e bordados como temas privilegiados. De acordo com Buitoni (2013), se considerarmos que segmentação faz referência a divisões de um grande conjunto, a imprensa feminina seria aquela que mais exercitaria o conceito. Cabe perguntar, contudo, de que modo tal conceito era, e ainda é, empregado e, para isso, uma linha histórica traçada por Buitoni (2013, p. 115) é ilustrativa.

Já no século XIX, os periódicos de moda representavam uma primeira segmentação no conjunto da imprensa feminina. Os produtos da Editora Abril também ilustram a tendência à segmentação: as duas primeiras publicações dirigidas às mulheres foram Manequim (moda e moldes) e Capricho (casa, comportamento, moda e principalmente fotonovelas), 1952 [...] Em 1961, Claudia inicia a carreira que a transformará na principal revista feminina do país: Essa revista foi gerando vários "fillhotes": Claudia Moda, Casa Claudia, Claudia Cozinha [...] Nova (1973), Marie Claire (1991) [...] Elle (1988) e Vogue Brasil (1975), nascidas a partir de modelos estrangeiros, dirigem-se a mulheres de estilos específicos. Vogue é identificada com o universo da moda [...] Elle, que de início apresentava um leque de editorias femininas, nos últimos anos voltou seu foco para a moda como eixo central [...] Corpo a Corpo [1987] e Boa Forma (1988) são indícios de que o culto ao corpo vinha para se estabelecer na sociedade brasileira.

Mira (1997, p. 68-69), também ao refletir sobre a segmentação, já ponderava que a revista seria "naturalmente" voltada às mulheres: "Na verdade, quando se fala em revista logo se pensa em mulher. A revista é a mídia mais feminina que existe. Tanto quanto o jornal é masculino". A autora aciona pesquisas referentes ao tema e enumera uma série de possíveis justificativas - embora já vá descartando algumas - para a existência desta "identifícação tão estreita entre a revista e a mulher": um formato menor e mais delicado, o fato de poder ser facilmente posta de lado mediante outras atribuições domésticas e, então, ser recuperada posteriormente sem prejuízos e, ainda, a construção de um mercado de consumo particular.

O que significa, entretanto, dizer que a revista é uma "mídia feminina"?

Para Veiga da Silva (2014, p. 102), é fundamental perceber que "a mídia e o jornalismo estão constituídos por gênero e produzem relações de gênero e de poder que resultam em saberes acerca disso". O gênero do jornalismo, diz, seria o masculino, uma vez que ele lidaria com um tipo de conhecimento historicamente produzido pelos homens e que as notícias refletiriam, em sua maioria, convenções sociais hegemônicas. Compreender de que modo as 
revistas que aqui estudamos (duplamente femininas) tratam/não tratam do mega-acontecimento que é a pandemia de Covid-19 em suas capas é nosso objetivo central.

\section{O quarteto investigado}

As revistas que miramos são publicações femininas mensais de grande destaque no Brasil. Dentre elas, Claudia é a única originária do país. Vogue, Marie Claire e Glamour são versões brasileiras de revistas criadas no exterior. Na breve apresentação que trazemos de cada uma, percebemos que pretendem falar para um público formado por mulheres que fogem do lugar comum, bem informadas, ousadas e engajadas.

Claudia (Editora Abril) surgiu no início dos anos 1960 e é a revista feminina de maior circulação mensal: São 177 mil exemplares em circulação no impresso e digital, com 81\% de seu público composto por mulheres, a maior parte com 35 a 44 anos. Suas leitoras se interessam por autenticidade, originalidade, histórias e lifestyle (MEDIA KIT CLAUDIA, 2019).

Vogue (Globo Condé Nast), lançada no Brasil em 1975, tem circulação mensal de 43.063 exemplares impressos e digitais, 72,7\% dos leitores são mulheres e mais da metade tem mais de 35 anos. A "mulher Vogue" é "Atitudinal e não de idade; Uma apaixonada por moda; Alto poder de consumo; Viajada e bem informada, e também é formadora de opinião no seu grupo; Procura a melhor curadoria em moda, beleza e lifestyle" (MEDIA KIT VOGUE, 2019, não paginado).

Marie Claire (Editora Globo), editada no país desde o início dos anos 1990, tem circulação de 171.642 exemplares, 92\% dos leitores mulheres e a maior parte entre 18 e 44 anos. Com leitoras que são independentes, inteligentes e que gostam de moda, "celebra a mulher contemporânea, fala para uma leitora ousada e ao mesmo tempo glamourosa" (MEDIA KIT MARIE CLAIRE, 2019, não paginado).

Glamour (Globo Condé Nast), veiculada no Brasil desde 2012, tem circulação de 50.500 exemplares das edições impressa e digital, $58,5 \%$ do público é feminino e a maioria tem mais de 25 anos. A leitora da revista "Possui uma causa; Busca tendência; Engajada e Empoderada; Mística; Aberta à experimentação; Body positive” (MEDIA KIT GLAMOUR, 2019, não paginado). 


\section{Capas como verbovisualidades}

Nosso olhar para as revistas se dá justamente a partir das capas. Inicialmente, porque este costuma ser o primeiro contato que temos com qualquer publicação, mesmo que nem cheguemos a tocá-la. Mas, ainda, porque a capa possui camadas e não tem como função exclusiva envolver o miolo (TRINDADE, 2019).

Página mais importante de qualquer revista (CARDOSO, 2006), para Kopp (2008) e Scalzo (2008), é uma espécie de síntese do que está por vir, mas não se trata de um resumo qualquer. A cada número, dizem, o leitor precisa entender que a edição mudou, sem, contudo, deixar de diferenciar uma publicação de suas congêneres. A identidade da publicação deve ser afirmada logo ali, até porque a escolha por ler uma ou outra revista associa-se a um modo de vida. Além de tudo isso, a capa precisa seduzir seu público.

Impressas, as publicações nos encaram em gôndolas estrategicamente posicionadas próximas aos caixas de livrarias, supermercados, drogarias. Em versão digital, chegam (sem o miolo) em nossos celulares, tablets e computadores por meio de seus sites e redes sociais oficiais ou mencionadas por qualquer outro autor da rede. É praticamente impossível não se deparar com elas.

Para abordar as múltiplas camadas das capas, apostamos na noção de dispositivo midiático, que articula "uma forma específica de manifestação material dos discursos, de formatação de textos" (ANTUNES; VAZ, 2006, p. 47). Tomada como dispositivo midiático, a capa inscreve um texto e orienta seu sentido. Não se trata, porém, de algo rígido. Mouillaud (2002), ao abordar a noção, lembra que texto e leitor não são passivos e também determinam o dispositivo.

Que texto seria esse? De modo sucinto, um texto que envolve elementos verbais e não verbais. A abordagem que Abril $(2007 ; 2013)$ confere aos textos é bastante representativa do que dizemos.

Entendemos que "texto" deve designar qualquer unidade de comunicação, geralmente multissemiótica (ou "multimodal", segundo o vocábulo da moda), sustentada por uma prática discursiva e inserida em uma(s) rede(s) textual(is), 
que pode integrar ou não elementos verbais, e que, portanto, não deve identificar-se restritivamente com eles ${ }^{6}$ (ABRIL, 2013, p. 46, tradução nossa).

O texto verbo-visual é lido/visto de forma social e coletiva, está enredado a outros e, portanto, sempre integra conjuntos. Sua significação cultural está relacionada a práticas sociais e relações de poder. Assim, devem ser lidos contextualmente e interpretados do ponto de vista histórico-cultural e discursivamente.

Para Abril (2013), o texto visual apresenta três dimensões inter-relacionadas e que permitem a efetuação uma da outra. A dimensão da visualidade, relacionada à trama visual, envolve também o invisível - o que se deseja ver, o que se sabe, o que se crê e o que se faz com o que se vê. A dimensão da mirada (ou olhar) refere-se à enunciação. Olhamos a capa e a capa nos olha. O texto prevê nosso lugar de espectador. Por fim, a dimensão da imagem, que não se refere necessariamente ao visual. Resulta de imaginários sociais, atua na criação de sentidos comuns, é histórica.

Observar as capas segundo as diferentes dimensões e na sua existência em rede nos parece um caminho produtivo para pensar a relação das mulheres com o jornalismo desenvolvido pelas revistas estudadas e na relação que esse jornalismo busca estabelecer com essas mulheres e com os acontecimentos que seriam ou não cabíveis ao seu público.

Como Antunes e Vaz (2006), não tomamos o processo comunicativo como integralmente midiático, mas não ignoramos seu lugar social. Assim, também nos é cara a contribuição de Hepp (2014) acerca do conceito de midiatização:

Em relação aos aspectos quantitativos, a midiatização refere-se à propagação temporal, espacial e social cada vez maior da comunicação midiática. Isso quer dizer que, com o tempo, temos nos tornado cada vez mais acostumados a nos comunicar pela mídia em vários contextos. Em relação aos aspectos qualitativos, a midiatização se refere ao papel da especificidade de certas mídias no processo de mudança sociocultural (HEPP, 2014, p. 51).

\footnotetext{
6 Original: Entendemos que "texto" ha de designar cualquier unidad de comunicación, generalmente multisemiótica (o "multimodal", según el vocablo de moda), sustentada por una práctica discursiva e inserta en una(s) red(es) textual(es), que puede integrar o no elementos verbales, y que por ende no debe identificarse restrictivamente con ellos (ABRIL, 2013, p. 46).
} 
Entram em jogo as especificidades de cada mídia e a apropriação que se faz delas. Hepp (2014) defende, ainda, que mídias diferentes coexistem, o processo é cumulativo. Isso nos ajuda a pensar nas capas que chegam em sua forma impressa e digital.

A partir dessa perspectiva da midiatização, tomamos as capas como dispositivos midiáticos que inscrevem textos verbo-visuais que, ao serem apropriadas, orientam experiências, comportamentos e modos de existência possíveis e impossíveis.

\section{O que dizem as capas?}

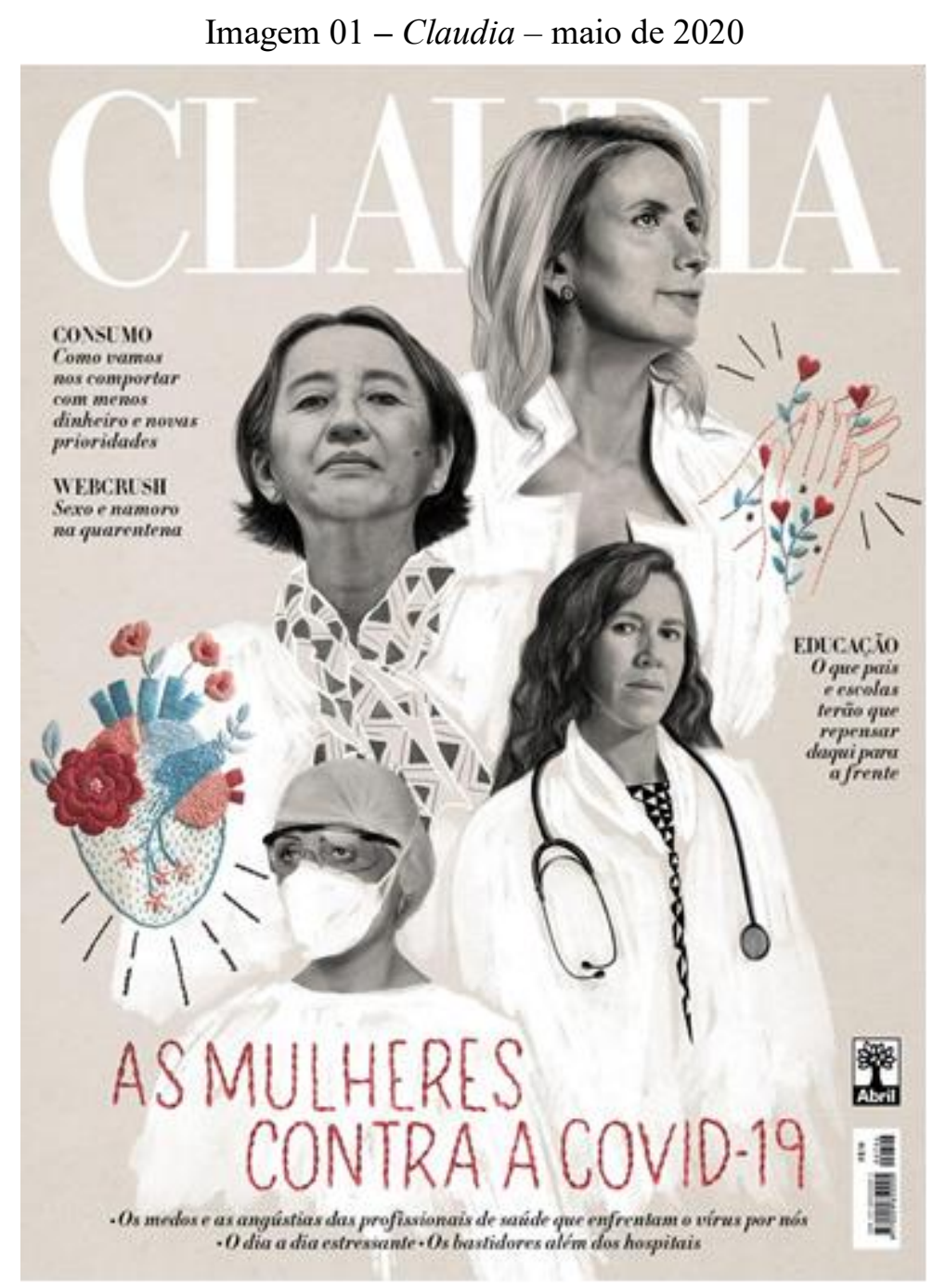

Fonte: Acervo pessoal dos autores. 
Sob um Claudia escrito em branco, e em fundo de cor bege, a edição de número 704 da revista trouxe na capa quatro mulheres, em fotografias sem coloração. Duas lançam olhares para outros espaços que não o da lente que as fotografou, parecem olhar para algo que, do mesmo modo, vaza à capa e escapa ao nosso olhar de leitores (um futuro mais promissor?). As outras olham diretamente para quem possui a capa em mãos (olhares tranquilos). Todas usam vestes em tons claros (traços de ilustração a partir das roupas originais) e duas, seguramente, são profissionais da área da saúde (uma traz um estetoscópio em volta do pescoço e a outra, máscara, óculos e touca normalmente utilizados por profissionais que acessam áreas hospitalares).

As cores mais intensas advêm da chamada principal, "As mulheres contra a Covid-19", e de duas imagens que, literalmente, costuram a capa: uma salva de palmas, de onde brotam flores em formato de coração (canto superior direito), e um coração de onde, por sua vez, brotam flores (canto inferior esquerdo). Chamada e imagens são traçadas por meio de linhas de costura.

Desde já, portanto, cabe refletir acerca dessa composição: os tons suaves e delicados, bem como a costura como opção de traçado, dialogam com lugares culturalmente estabelecidos como femininos. Ainda que trate de uma pandemia e que mostre mulheres em posição de destaque na luta contra o vírus, a capa parece reiterar lógicas estáveis e essencialistas, ao pensar o gênero e o modo como suas leitoras podem/devem performá-lo (BUTLER, 2012).

Junto à chamada principal, há manchetes explicativas: “Os medos e as angústias das profissionais de saúde que enfrentam o vírus por nós"; "O dia a dia estressante" e "Os bastidores além dos hospitais" (AS MULHERES..., 2020, p. 1). De maneira geral, reiteram um sentido que, em nosso movimento de análise, pareceu central na composição visual: ainda que existam mulheres enfrentando a pandemia, tal universo é, fundamentalmente, masculino e, ao fazê-lo, tais mulheres levam consigo "traços" que são então tomados como "naturais" e não como construções ideológicas e políticas (WITTIG, 2010). Do mesmo modo como as cores, os olhares e a costura dizem de um mundo de mulheres, os medos, as angústias e o stress, opostos à coragem "genuinamente" masculina e mais "necessária” em uma pandemia, materializam-se diante de nós como marcas de mulheres. Ainda nesse sentido, pensando em relação ao leitor modelo (ECO, 1988), supõe-se que essa leitora não é a mulher que estampa a capa (que enfrenta a pandemia por nós) e, ainda, que mais do que falar da pandemia e de seu enfrentamento, essas 
mulheres são aptas para falar sobre "os bastidores além dos hospitais" que, podemos supor, fazem referência ao ambiente doméstico/familiar (atribuídos ao feminino).

Há, ainda, três chamadas, cada uma delas encabeçada por uma palavra em destaque: "CONSUMO - como vamos nos comportar com menos dinheiro e novas prioridades"; "WEBCRUSH - sexo e namoro na quarentena e "EDUCAÇÃO - o que pais e escolas terão de repensar daqui para a frente”. Nelas pode-se observar a construção de uma mulher assinalada por estereótipos e lugares comuns. A manchete relativa ao consumo sinaliza uma preocupação mediante o fato de que, em meio a uma recessão potencializada pela pandemia, comprar menos seria necessário (o que seria um desafio). A manchete relativa aos relacionamentos afetivos e sexuais sinaliza um modo de driblar a carência (algo também ideologicamente ligado ao feminino) em meio ao isolamento (relacionamento virtual). Por fim, a manchete sobre educação reitera a percepção culturalmente estabelecida de que cuidados com a educação dos filhos é uma prioridade materna (ainda que, curiosamente, o texto diga "pais").

Imagem 02 - Vogue - maio 2020

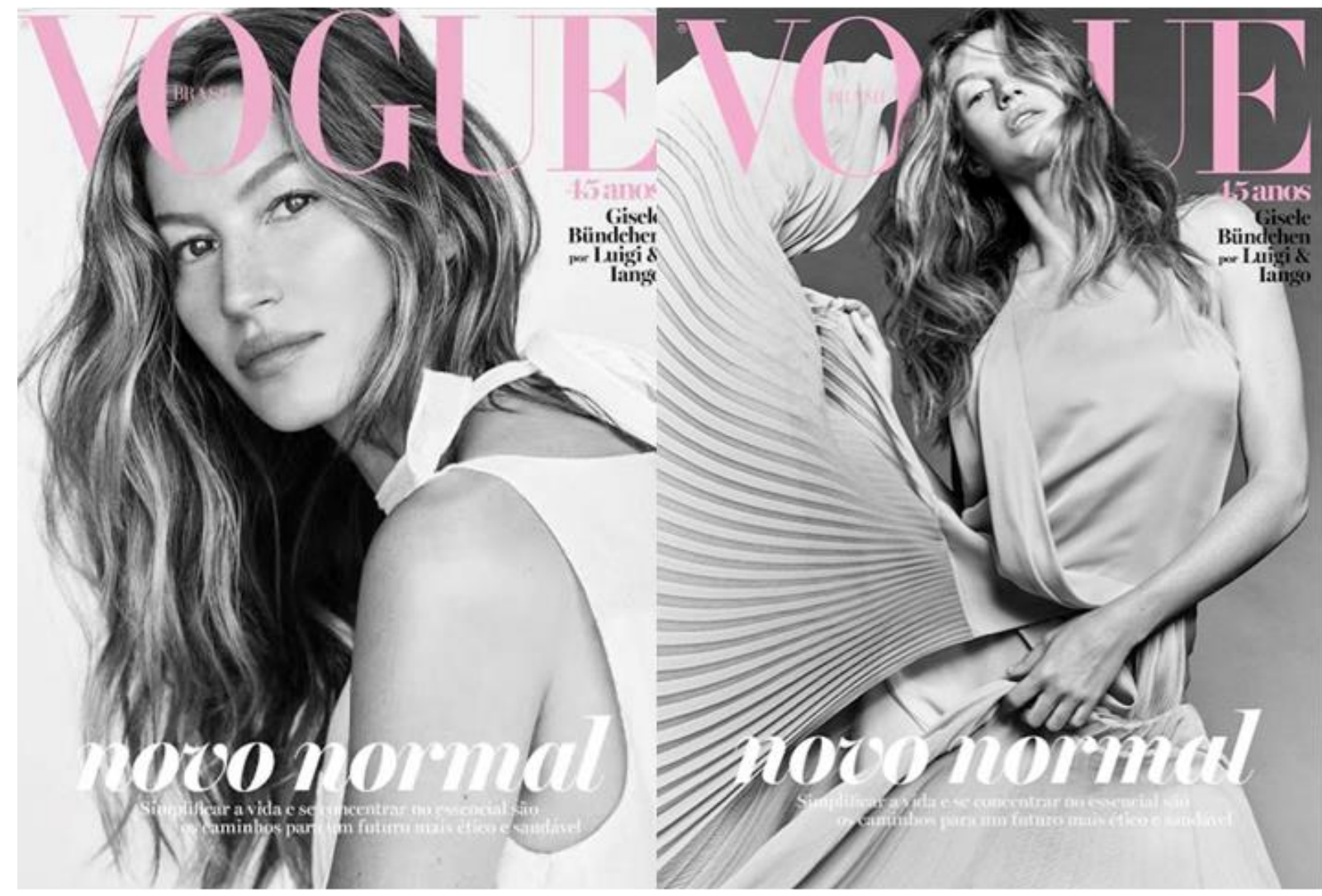

Fonte: Acervo pessoal dos autores. 
Propulsoras de polêmicas nas redes sociais digitais (ESTEVÃO, 2020), as capas de maio da Vogue nacional trouxeram, também em preto e branco, a modelo brasileira Gisele Bündchen. O colorido da composição (rosa claro) advém do título da revista, que encabeça as capas, e, ainda, do "45 anos" que o acompanha (evidenciando que se trata de uma edição comemorativa do título no país). A manchete principal ("novo normal”), em branco, letras minúsculas, é acompanhada por uma legenda grafada na mesma coloração (o que diminui a legibilidade e importância) que diz: "simplificar a vida e se concentrar no essencial são os caminhos para um futuro mais ético e saudável".

Em uma delas, Gisele, com roupas, cabelos e pele claros, encara leitoras e leitores de modo tranquilo, sereno. Na outra, em uma pose dramática, também vestida em tons claros, joga uma saia, de tecido leve e plissado, que acaba por ocupar metade do espaço da composição. Em ambas, ainda que veiculadas em um contexto de pandemia, o mega-acontecimento (SANTOS, 2005 ) é reduzido ao termo "novo normal " (com o qual se passou a se designar a sobrevivência em meio ao vírus) e, para além disso, nada mais específico é dito.

As roupas, embora essa informação não esteja explícita na capa, são das grifes Prada e Chloé. O ensaio, soube-se depois, foi realizado antes do isolamento social e estava guardado, esperando uma oportunidade (talvez um não-acontecimento?) para ser publicado. Mediante críticas recebidas em redes sociais, Daniela Falcão, CEO da Globo Condé Nast, confirmou que a edição já estava quase pronta, que não pode ser alterada mesmo diante do cenário da pandemia e que, na moda, o termo "novo normal" faria referência a "menos carão, mais simplicidade, mais amor e otimismo" (denotando que nem o termo em si seria diretamente relacionado à pandemia) e que, ainda, a capa representaria "sensibilidade de saber quem somos, de permanecer fiel ao [...] dna ao mesmo tempo em que se reflete sobre tantas mudanças" (DIAS, 2020, não paginado).

Temos, enfim, em ambas as opções de capa de Vogue, o ruidoso silenciamento de uma modelo, em roupas de grife, ensinando às leitoras e aos leitores da revista do que se tratava o novo normal que todos enfrentávamos e, do mesmo modo, sinalizando o que era relevante e irrelevante nesse contexto. 


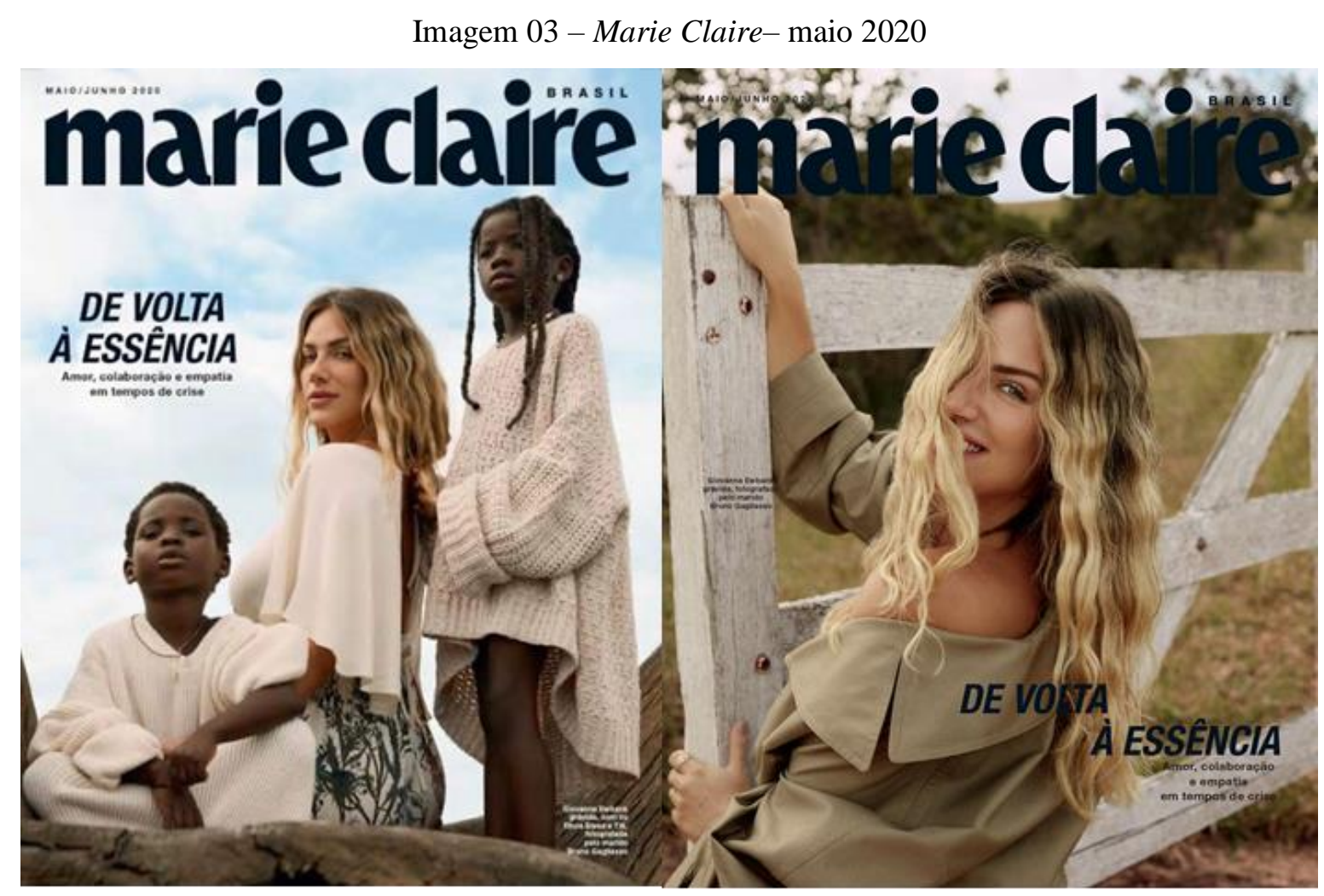

Fonte: Acervo pessoal dos autores.

A edição de maio/junho de 2020 de Marie Claire Brasil trouxe duas opções de capa. Na primeira, para o público em geral, sobre o que parecem ser raízes de uma árvore e com o céu como paisagem, Giovanna Ewbank posa com os filhos Bless e Titi para o marido Bruno Gagliasso - crédito fotográfico que aparece na legenda da foto, junto com a informação de que Giovanna está grávida. O nome da revista, em preto, está estampado entre as nuvens, assim como a única chamada de capa: "De volta à essência - Amor, colaboração e empatia em tempos de crise". Nessa capa, os três vestem roupas claras e confortáveis e Titi não encara o leitor (nem o pai que fotografa), mas Bless e a mãe, sim.

A construção da capa aponta para a tentativa da publicação de remontar ao que a revista chama de "essencial" diante da pandemia: a família, uma vida simples, proximidade com a natureza, roupas confortáveis. Em alguma medida, pode-se dizer que Marie Claire estaria prestando um serviço ao tentar cuidar da saúde mental de sua leitora, mas a capa vai muito além disso. 
A família aí retratada tem a mãe como elemento central. O pai, que fotografa, é apenas um observador e o alicerce desse núcleo é feminino, simbolizado por Giovanna. Importante ressaltar que se trata de uma família que naquele momento tinha condições de aderir ao isolamento social, dedicar-se aos cuidados com os filhos e, ainda, ficar em contato com a natureza. Essa não é, em todos esses âmbitos, a realidade da maior parte das famílias.

Se nos voltamos para os trajes dos três, percebemos que a tendência comfy wear, associada aos tempos pandêmicos vividos em grande parte no ambiente doméstico, marca as roupas off-white da família - reconhecidos ícones fashion nas redes sociais brasileiras. Essa informação de moda não pode ser ignorada.

Na segunda opção, para assinantes, novamente nos deparamos com Giovanna, mais uma vez fotografada pelo esposo e, também, acompanhada pela mesma chamada de capa. Nessa imagem ela aparece sozinha. A essência, aqui, parece estar relacionada fortemente a um universo campestre, primitivo, original, o que é manifesto via presença de uma cerca, aparentemente de fazenda, na qual Giovanna se apoia e, ainda, em um fundo que, mesmo borrado, explicita árvores e um gramado. Sorridente, a atriz olha para trás e, assim, para seu marido e para quem possui a revista diante de si. A roupa, igualmente confortável, agora em tons terrosos, expõe o ombro. Os cabelos, que cobrem parte do rosto, parecem igualmente "naturais", soltos.

Marie Claire retrata uma vivência inquestionavelmente privilegiada da pandemia. $\mathrm{Na}$ primeira capa, aloca a mulher como central no espaço doméstico, destaca seu papel como mãe e, ademais, trata esse modo de existência como essencial, reservando ao pai/companheiro o espaço do observador. Trata-se de uma capa fortemente patriarcal (SAFFIOTI, 2015) e heteronormativa (WARNER, 1991). Na segunda, personifica em Giovanna (rica, branca, inserida dentro de um padrão estético hegemônico) modos não de sobreviver à pandemia, mas de passar por ela serena, tranquila e feliz em um lugar bucólico que, certamente, não é uma opção para todas as leitoras. 


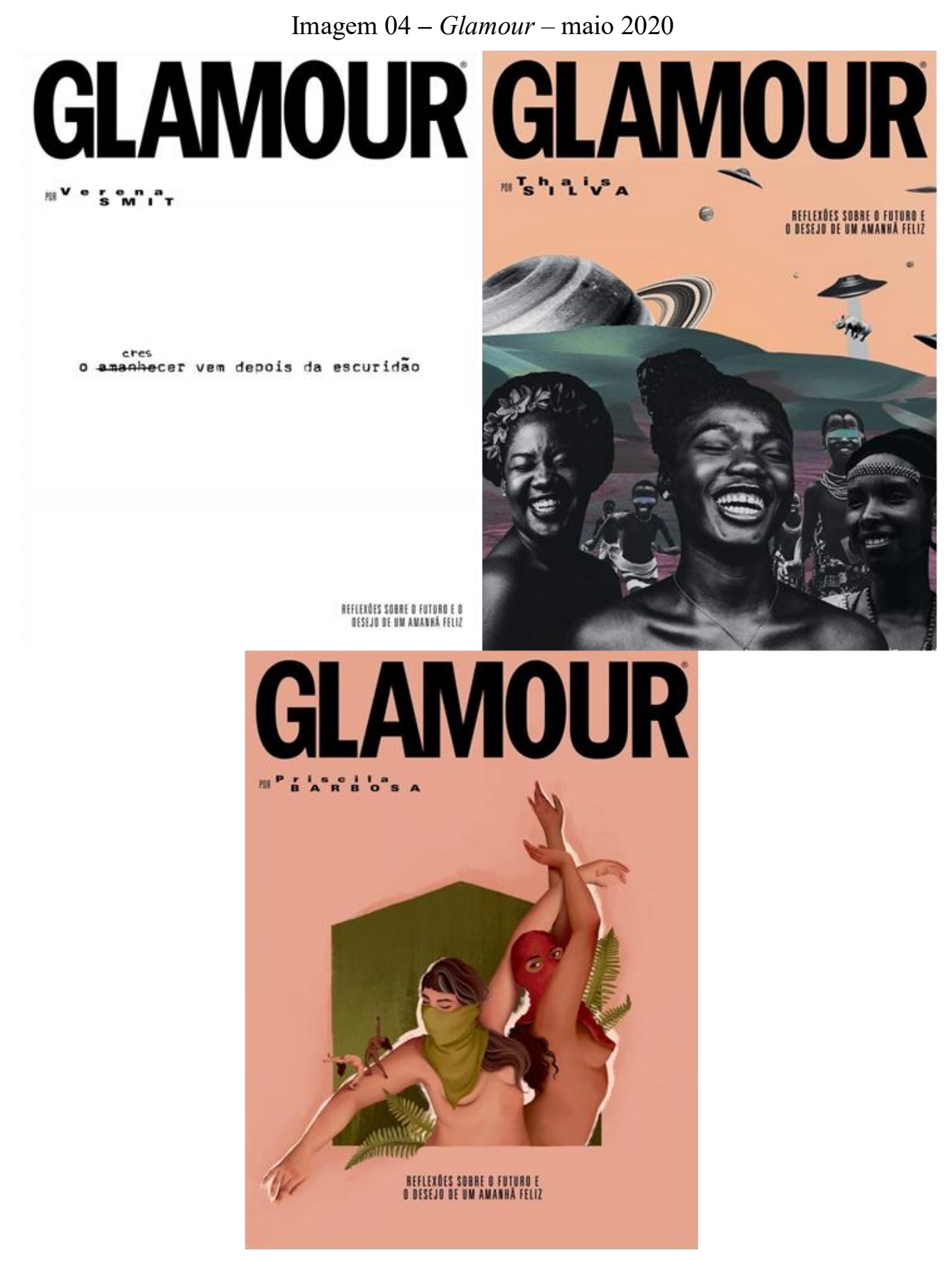

Fonte: Acervo pessoal dos autores.

As três capas de Glamour, cada uma elaborada por uma mulher diferente (presentificadas por meio de seus nomes impressos logo abaixo da logomarca da revista, à esquerda e, portanto, em um lugar de destaque), trazem distinções, mas trabalham todas a partir 
da seguinte manchete: "Reflexões sobre o futuro e o desejo de um amanhã feliz". Tal chamada aponta para a possibilidade de um futuro melhor pós-pandemia. As capas, ainda que salvaguardadas suas singularidades, estampam a esperança e sinalizam os modos possíveis de alcançar esse amanhã mais promissor.

A primeira capa trabalha com tipografia em preto sobre a sensação de falta proporcionada pela cor branca que inunda nossa visão. O branco, cabe destacar, pode representar, ainda, tanto a ausência de cor, como, ao mesmo tempo, todas as cores. Trata-se, pois, de uma capa, de um ponto de vista metafórico, fortemente inclusiva e plural. Essa capa sugere o momento atual como uma espécie de transição para dias melhores, ressignificando o luto (que seria marcado pela cor preta) a partir de seu oposto (cor branca) e posicionando o atual momento como, também, um lugar para se crescer e se evoluir. Nela lemos a frase: "O cresamanhecer vem depois da escuridão", o que reforça a metáfora mencionada.

As duas outras capas nos parecem ainda mais complementares. Uma delas, sobre um fundo rosa (cor culturalmente relacionada ao feminino), traz a felicidade encarnada em uma colagem com imagens de mulheres e meninos negros que, sorrindo, ganham destaque por estarem impressos em preto e branco. Discos e outros elementos espaciais complementam a página e parecem estar ali apontando para o futuro, ao mesmo tempo que alguns acessórios das/dos fotografadas/os remetem a uma origem/matriz anterior, arcaica. A capa, acreditamos, reúne passado e futuro em um movimento que sinaliza integração, ressignificação, utopia. A última capa, também sobre um fundo rosa, traz mulheres diferentes, em relação entre si e com a natureza. Elas dançam, apoiando-se uma em relação às outras. A mulher que está ao centro, branca, não magra e, ainda que aparentemente jovem, com mechas grisalhas, apoia em seu braço duas pequenas mulheres nuas (uma branca e uma negra). Essa mulher ao centro, igualmente nua, traz um dos seios coberto por um pano/máscara verde - símbolo da luta feminista argentina pela legalização do aborto - e o outro por uma mecha de cabelo. Ao seu lado, uma mulher negra, nua e com os seios cobertos por uma máscara vermelha que desce até o peito, a apoia/a sustenta. Dentre múltiplos sentidos então engendrados, a ênfase no apoio/solidariedade entre mulheres é central. Para além disso, ramos de samambaia parecem brotar de duas destas mulheres, reiterando uma perspectiva que integra a mulher à natureza, remetendo também a uma matriz arcaica/neopagã (o que, também sob nossa percepção, é 
reforçado pelos movimentos dos corpos, os quais remetem aos rituais do sabá) (RUSSELL; ALEXANDER, 2019). Essa capa e a anterior parecem dizer que o futuro será um tempo melhor justamente por conta da presença de mulheres diversas em relação e por conta da conexão dessas mulheres com a natureza. Essas três capas, feitas por mulheres (reiteramos), apontam para o feminino e sua conexão com a natureza como evolução, como uma forma de alimentar a esperança de que dias melhores são possíveis.

\section{Considerações finais}

Compreender de que maneira, nas capas do mês de maio das revistas Claudia, Vogue, Marie Claire e Glamour, a pandemia de Covid-19 foi/não foi representada, correspondeu a inquietação que nos mobilizou nesta investigação.

Ao empreendermos um exercício de análise que percebeu tais capas como dispositivos midiáticos que inscrevem textos verbo-visuais e, ainda, ao compreendermos que, na condição de dispositivos discursivos das feminilidades, tais capas sinalizam caminhos permitidos e interditados às mulheres que com elas se deparam, tentamos perceber as distintas camadas de significação que ali se constituíam.

Em Claudia, constatamos que mulheres também podem ocupar posições de destaque no combate ao vírus, mas que, ao fazê-lo, trazem consigo marcas que dizem de seus lugares no mundo (um mundo masculino) como mulheres. Em Vogue, com Gisele, observamos como um não-acontecimento, um novo normal que, em letras minúsculas, se refere ao DNA da revista, sobrepuja a pandemia e tudo o que vem com ela (mega-acontecimento e seus diversos campos problemáticos). Em Marie Claire aprendemos como ser mãe/ser mulher em meio à pandemia e ao isolamento social daí decorrente. Se você for jovem, rica, magra, loira e inserida dentro de um padrão estético, você pode sempre ir para um retiro campestre e pedir ao seu marido/galã um ensaio fotográfico. Em Glamour, por outro lado, observamos modos distintos de construção/representação do feminino. A revista aciona lugares plurais de existência e de sobrevivência feminina, dizendo que sim, haverá um amanhã - pertencente às mulheres.

\section{Referências}

ABRIL, Gonzalo. Análisis crítico de textos visuales. Madrid: Editorial Sintesis, 2007. 
ABRIL, Gonzalo. Cultura visual, de la semiótica a la política. Madrid: Plaza y Valdés, 2013.

ANTUNES, Elton; VAZ, Paulo Bernardo. Mídia: um aro, um halo e um elo. In: GUIMARÃES, César; FRANÇA, Vera (org.). Na mídia, na rua: narrativas do cotidiano. Belo Horizonte: Autêntica, 2006. p. 43-60.

AS MULHERES contra a Covid-19. Cláudia, [São Paulo], p. 1, maio 2020.

BRASIL registra 826 mortes por Covid-19 em 24 horas e chega a 140.709. G1, 25 set. 2020, Bem Estar, não paginado. Disponível https://g1.globo.com/bemestar/coronavirus/noticia/2020/09/25/casos-e-mortes-porcoronavirus-no-brasil-em-25-de-setembro-segundo-consorcio-de-veiculos-de-imprensa.ghtml. Acesso em: 30 set. 2020.

BUITONI, Dulcilia Schroeder. Revista e segmentação: dividir para reunir. In: TAVARES, Frederico de Mello Brandão; SCHWAAB, Reges. A revista e seu jornalismo. Porto Alegre: Penso, 2013. p. 107-118.

BUTLER, Judith. El capitalismo tiene sus límites. In: AMADEO, Pablo (ed.). Pensamiento contemporáneo en tiempos de pandemias. Buenos Aires, Argentina: Medianegro, 2020. p. 59-66. [ASPO - Aislamiento Social Preventivo y Obligatorio].

BUTLER, Judith. Problemas de gênero: feminismo e subversão da identidade. São Paulo: Editora Record, 2012.

CARDOSO, Carla Rodrigues. As capas de newsmagazines como dispositivo de comunicação (Newsweek, Veja, L'Express e Visão - janeiro a março de 1999). 2006. Dissertação (Mestrado em Ciências da Comunicação) - Departamento de Ciências da Comunicação, Faculdade de Ciências Sociais e Humanas, Universidade Nova de Lisboa, Lisboa, 2006.

CASOS de coronavírus e número de mortes no Brasil em 8 de maio. G1, 8 maio 2020. Bem Estar, não paginado. Disponível em: https://g1.globo.com/bemestar/coronavirus/noticia/2020/05/08/casos-de-coronavirus-enumero-de-mortes-no-brasil-em-8-de-maio.ghtml. Acesso em: 30 set. 2020.

COVID-19 Dashboard by the Center for Systems Science and Engineering (CSSE) at Johns Hopkins University (JHU). 2020. Disponível em:

https://gisanddata.maps.arcgis.com/apps/opsdashboard/index.html\#/bda7594740fd402994234 67b48e9ecf6 Acesso em: 30 set. 2020.

COVID-19: os números e as notícias de sexta-feira, 8 de maio. Euronews, 8 maio 2020. Mundo, não paginado. Disponível em: https://pt.euronews.com/2020/05/08/covid-19-osnumeros-e-as-noticias-de-sexta-feira-8-de-maio. Acesso em: 30 set. 2020. 
DE VOLTA à essência. Marie Claire, São Paulo, p. 1, maio 2020.

DE FONTCUBERTA, Mar. La noticia. Barcelona: Editorial Paidós, 1993.

DIAS, Leo. Vogue não fala da capa de maio, mas editora se explica nas redes sociais. Uol. Disponível em: https://tvefamosos.uol.com.br/colunas/leo-dias/2020/05/07/vogue-nao-fala-decapa-de-maio-mas-editora-responde-nas-redes-sociais.htm Acesso em: 30 set. 2020.

ECO, Umberto. Lector in fabula. São Paulo: Perspectiva, 1988.

ESTEVÃO, Ilca Maria. Entenda a polêmica por trás das capas da Vogue Brasil de maio e junho. Metrópoles. Disponível em: https://www.metropoles.com/colunas/ilca-mariaestevao/entenda-a-polemica-por-tras-das-capas-da-vogue-brasil-de-maio-e-junho. Acesso em: 30 set. 2020.

FISCHER, Rosa Maria Bueno. O dispositivo pedagógico da mídia: modos de se educar na (e pela) TV. Educação e Pesquisa, São Paulo, v. 28, n. 1, p. 151-162, jan./jun. 2002.

HEPP, Andreas. As configurações comunicativas de mundos midiatizados: pesquisa da midiatização na era da "mediação de tudo". Revista MATRIZes, São Paulo, v. 8, n. 1, p. 4564, 2014.

KOLINSKI MACHADO, Felipe Viero. Homens que se veem: masculinidades nas revistas Junior e Men's Health Portugal. Ouro Preto, MG: Editora UFOP, 2018.

KOPP, Rudinei. Design para capas de revistas: padronização e flexibilização. In: FELIPPI, Ângela; SOSTER, Demétrio de Azeredo; PICCININ, Fabiana (org.). Edição de imagens em jornalismo. Santa Cruz do Sul: EDUNISC, 2008. p. 210-240.

LAURETIS, Teresa de. A tecnologia do gênero. In: HOLANDA, Heloisa Buarque de (org.). Tendências e impasses: o feminismo como crítica da cultura. Rio de Janeiro: Rocco, 1994. p. 206-242.

MEDIA KIT CLAUDIA. Disponível em: http://publiabril.abril.com.br/marcas/claudia. Acesso em: 30 set. 2020.

MEDIA KIT GLAMOUR. Disponível em: https://irpcdn.multiscreensite.com/43f3dabf/files/uploaded/GL_MIDIAKIT_2019.pdf. Acesso em: 30 set. 2020.

MEDIA KIT MARIE CLAIRE. Disponível em: http://anuncie.infoglobo.com.br/editoraglobo/marcas/marie-claire.html Acesso em: 30 set. 2020.

MEDIA KIT VOGUE. Disponível em: https://irpcdn.multiscreensite.com/43f3dabf/files/uploaded/VG_MIDIAKIT_2019.pdf Acesso em: 30 
set. 2020 .

MIRA, Maria Celeste. O leitor e a banca de revistas: o caso da Editora Abril. 1997. Tese (Doutorado em Sociologia) - Instituto de Filosofia e Ciências Humanas, Universidade Estadual de Campinas, Campinas, São Paulo, 1997.

MOREIRA, Ardilhes; PINHEIRO, Lara. OMS declara pandemia de coronavírus. G1, 11 mar. 2020. Bem Estar, não paginado. Disponível em: https://g1.globo.com/bemestar/coronavirus/noticia/2020/03/11/oms-declara-pandemia-decoronavirus.ghtml. Acesso em: 30 set. 2020.

MOUILLAUD, Maurice. Da forma ao sentido. In: MOUILLAUD, Maurice; PORTO, Sergio Dayrell; PORTO, Sérgio Grossi. O jornal: da forma ao sentido. Brasília: Ed. UnB, 2002.

NOVO NORMAL. Vogue, São Paulo, p. 01, maio 2020.

PRECIADO, Paul B. Aprendiendo del virus. In: AMADEO, Pablo (ed.). Pensamiento contemporáneo en tiempos de pandemias. Buenos Aires, Argentina: Medianegro, 2020. p. 163-185. [ASPO - Aislamiento Social Preventivo y Obligatorio].

PRECIADO, Paul B. Manifesto contrassexual. São Paulo: N-1 Edições, 2014.

QUÉRÉ, Louis. Entre facto e sentido: a dualidade do acontecimento. Trajectos, Lisboa, v. 6, n. 6, p. 59-76, 2005.

REBELO, José. Prolegómenos à narrativa mediática do acontecimento. Trajectos, Lisboa, n. 8-9, p. 17-27, 2006.

REFLEXÕES sobre o futuro e o desejo de um amanhã feliz. Glamour, [São Paulo], p. 1, maio 2020 .

RUSSELL, Jeffrey B.; ALEXANDER, Brooks. História da bruxaria: feiticeiras, hereges e pagãs. São Paulo: Aleph, 2019.

SAFFIOTI, Heleieth. Gênero, patriarcado, violência. 2. ed. São Paulo: Expressão Popular: Fundação Perseu Abramo, 2015.

SANTOS, José Manuel. Da perca do mundo à sociedade dos (mega) acontecimentos. Trajectos, Lisboa, n. 6, p. 77-83, 2005.

SCALZO, Marília. Jornalismo de revista. São Paulo: Contexto, 2008.

TAVARES, Frederico de Mello B.; SCHWAAB, Reges. Revista e Comunicação: percursos, lógicas, circuitos. In: TAVARES, Frederico de Mello B.; SCHWAAB, Reges. A revista e seu jornalismo. Porto Alegre: Penso, 2013. p. 27- 43. 
TRINDADE, Vanessa Costa. Mulheres na Tpm: o corpo e a configuração de modos de ser mulher na capa da revista feminina. Belo Horizonte: UFMG, 2019. Tese (Doutorado em Comunicação Social) - Programa de Pós-Graduação em Comunicação Social, Faculdade de Filosofia e Ciências Humanas, Universidade Federal de Minas Gerais, Belo Horizonte, 2019.

VEIGA DA SILVA, Marcia. Masculino, o gênero do jornalismo: modos de produção das notícias. Florianópolis: Insular, 2014.

WARNER, Michael (editor). Fear of a Queer planet: Queer politics and social theory. Minneapolis, London: University of Minnesota Press, 1991.

WITTIG, Monique. El pensamiento heterosexual y otros ensayos. Barcelona: Egales, 2010.

ZIZEK, Slavoj. El coronavirus es un golpe al capitalismo a lo Kill Bill .... In: AMADEO, Pablo (ed.). Pensamiento contemporáneo en tiempos de pandemias. Buenos Aires, Argentina: Medianegro, 2020. p. 21-28. [ASPO - Aislamiento Social Preventivo y Obligatorio].

Submetido em: 04. 10. 2020.

Aprovado em: 09.11.2020. 